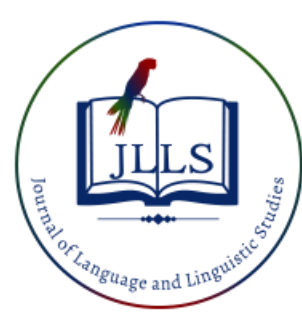

Available online at www.jlls.org

JOURNAL OF LANGUAGE AND LINGUISTIC STUDIES

ISSN: $1305-578 \mathrm{X}$

Journal of Language and Linguistic Studies, 16(4), 2024-2039; 2020

\title{
Students' and instructors' evaluation of a foreign language textbook from an intercultural perspective
}

\author{
Nur Gedik Bal a 1 iD \\ ${ }^{a}$ Social Sciences University of Ankara, Ankara, Turkey
}

\section{APA Citation:}

Gedik Bal, N. (2020). Students' and instructors' evaluation of a foreign language textbook from an intercultural perspective. Journal of Language and Linguistic Studies, 16(4), 2023-2038.

Submission Date: 18/07/2020

Acceptance Date: $31 / 08 / 2020$

\begin{abstract}
As teachers primarily rely on textbooks in the teaching of foreign languages, one way of helping and encouraging them to focus on intercultural competence (IC) is to provide them with the textbooks that facilitate intercultural language learning process. Therefore, this study aimed to evaluate the New Language Leader Pre-intermediate textbook from an intercultural perspective. This evaluation was primarily based on 132 students' and 15 instructors' perceptions of the textbook after they used it for two months in language classrooms at a preparatory school of a state university. The data collection instrument was a questionnaire adopted from a previous study. Data analysis was conducted with the help of SPSS 20.0. Descriptive Statistics was run to identify the frequencies and mean scores. Mann-Whitney U test was used to discover any possible significant difference in students' and instructors' perspectives. The results indicated that although most of the IC components such as knowledge, attitudes, awareness, and linguistic means existed in the textbook according to the participants, the extent of the representation of these in the textbook varied. Whereas the aims and goals of the textbook were thought to be in accordance with the conceptual framework of the students to a large extent, both students and instructors indicated that it did not provide much insight into learners' own culture. Considering the findings, the stakeholders might have necessary revisions on the textbook and instructors might adapt some resources to fulfil the needs of their learners in the development of IC in similar contexts.
\end{abstract}

(C) 2020 JLLS and the Authors - Published by JLLS.

Keywords: culture and language; intercultural competence; textbook evaluation; foreign language learning; English as an international language

\section{Introduction}

Intercultural competence (IC) has been defined in various ways for the last two decades. Whereas some scholars emphasized the effective management of interaction by culturally distinctive individuals, who represent diversified cognitive, behavioural, and affective approaches to the world (Spitzberg \& Changnon, 2009), others underlined the development aspect and adaptability to various cultural

\footnotetext{
${ }^{1}$ Corresponding author.

E-mail address: nur.gedikbal@asbu.edu.tr
} 
frameworks (Bennett \& Bennett, 2004; Hammer, 2015). Spitzberg and Changnon (2009) even classified contemporary models as the causal process, co-orientational, compositional, and developmental.

In the foreign language teaching context, one of the co-orientational models, which value mutual understanding, was Byram's (1997) model of IC. This model differentiated the terms 'bicultural' and 'intercultural'. Whereas intercultural speaker was defined as a mediator between their own cultures and cultures of others and an interlocutor successful in negotiation with a flexible identity, a bicultural individual was considered as a speaker who is experienced in two cultures but has conflicts regarding identity (Spitzberg \& Changnon, 2009). Model of IC (Byram, 1997) consisted of different components such as skills of discovery and interaction, skills of interpreting and relating, knowledge, attitudes, and critical cultural awareness, which were frequently cited by scholars in an effort to guide the language instructors in the teaching and assessment of IC.

IC was also emphasized as one of the primary aims of language learning and teaching by the Council of Europe (2018) and the companion volume included many updated descriptors under the title of 'Plurilingual and pluricultural competence'. It has been noted that learners should be trained as the intercultural speakers since being competent at linguistics alone does not address the needs of the language learners to engender successful communication with culturally unique individuals.

In order to raise language learners who are intercultural speakers, teachers should be equipped with intercultural knowledge and competencies first. Nevertheless, Hatipoğlu (2012) reported that preservice language teachers in even prestigious universities in Turkey had limited knowledge regarding the target culture upon exposure to English for at least eight years; therefore, she emphasized the necessity to have materials that can equip pre-service teachers with such cultural knowledge. On the other hand, equipping future language teachers with the knowledge of the target and other international cultures will not be sufficient considering the in-service language teachers who have already missed the opportunities to have culture courses in their undergraduate studies. Veteran teachers working in the field also need guidance and even training on how to integrate IC in their classrooms (e.g. Atay, 2005; Ghanem, 2017; Kelly, 2012; Liddicoat, Papademetre, Scarino, \& Kohler, 2003; Ryan, 2012; Sercu, 2005; Zhang, 2017).

One quick way of helping and encouraging in-service teachers to focus on IC during their language teaching is to provide them with the textbooks that facilitate this learning process as course books are a significant component of the curriculum and they assume a leading role in conveying cultural knowledge. They might be the sole or even the best sources to reach otherness for language learners in some contexts (Garcia, 2005). On the other hand, as Cortazzi and Jin (1999) indicated, the role of a textbook can be a guide, an ideology, or an authority, so it differs in various contexts. Amerian and Pouromid (2018) also acknowledge that the effectiveness of a textbook depends on how it is exploited by the teachers and learners in the classroom. In certain contexts, the textbook is viewed as a resource that can be benefited selectively whereas in others it is considered as scripts to be followed. However, as Tomlinson (2012) previously acknowledged, textbooks still dominate the language learning materials although there are arguments for or against the textbooks.

Evaluation of the textbook from an intercultural perspective, therefore, might provide some insight into what should be done further to help teachers in their endeavour to teach IC in the classroom. As teachers primarily depend on the textbooks and materials in the teaching of foreign languages and cultural issues (Kahraman, 2016), inadequacies might be detected and the textbooks could be revised or some supplementary materials, and activities might be developed to close the gap. Besides, teachers may be trained about how to exploit available resources to promote IC skills in language learners. 


\subsection{Literature review}

In this review, the textbook categorization provided by Cortazzi and Jin (1997) was frequently referred to. Target culture refers to the culture of English-speaking countries, source culture refers to students' own culture and international culture refers to any other cultures that use English as an international language (EIL). The textbook evaluation studies regarding IC can be classified based on their preference of the textbook under investigation (i.e. locally published and internationally published textbooks). A large number of studies (Abbasian \& Biria, 2017; Äijälä, 2009; Aliakbari, 2004; Çakır, 2010; Çelik \& Erbay, 2013; Demirbaş, 2013; Karahan Üzülmez \& Karakuş, 2018; Majzadeh, 2002; Siddiqie, 2011) focused on locally-produced textbooks in different contexts and some of these (Abbasian \& Biria, 2017; Çakır, 2010; Majzadeh, 2002) reported that there was more source culture content in these textbooks whereas others (i.e. Çelik \& Erbay, 2013; Demirbaş, 2013; Siddiqie, 2011) revealed that textbooks included international cultures though target culture content was more observable. Many studies (Alsaif, 2016; Alsofi, 2018; Amarian \& Tajabadi,2020; Böcü \& Raz1, 2016; Çetin-Köroğlu, 2016; Dimici, Yıldız \& Basbay, 2018; Erdoğan, 2015; Göktaş, 2013; Kayapınar, 2009; Shin, Eslami, \& Chen, 2011; Taş, 2010; Tozun, 2012) were also conducted on the internationally produced textbooks. This study aimed to evaluate an internationally published textbook; therefore, a brief review of literature focused on the evaluation of such textbooks here.

In the Saudi context, Alsaif (2016) analysed a language textbook called 'Touchstone' via textual analysis with the perspective of critical pedagogy and problematized the excessive focus on western cultures and neglecting source culture in language textbooks. Alsofi (2018) had a content analysis on a textbook which is named as 'Well Read 1'. He aimed to identify to what extent target, international, and source culture were represented in the textbook and how they were presented. The findings revealed that the textbook had integrated various cultures and focused on multiculturalism rather than specifically target cultures such as British or American; however, elements of source culture were minimal. Shin et al. (2011) analysed seven international textbooks and they reported that American and British cultures were still dominant in the textbooks. The presentation of the cultural elements was also at the knowledge level.

In the Turkish context, Dimici et al. (2018) investigated the perceptions of the instructors at a preparatory program about the 'English File' textbook and carried out content analysis. The results indicated that visual, audial, and written texts involved gender, and ethnicity dimensions although political orientation, disability, and social class were rarely seen. Kayapınar (2009) and Taş (2010) also analysed the same English textbook. They found that although it had a multicultural perspective, the cultural content of the textbook series was mainly on target culture and it lacked source culture elements. Similarly, Göktaş (2013) investigated instructors' and students' perspectives of 'English Unlimited' and found out that it did not motivate students to think about stereotypes and develop tolerance and sensitivity toward other cultures. Students wanted to see more cultural information about their own culture. Böcü and Razı (2016) had an evaluation study on 'Life A1/A2' textbooks. They did both content analysis and enquired 26 students' and six teachers' opinions via a questionnaire and interviews. The results indicated that big $\mathrm{C}$ and small $\mathrm{c}$ themes were fairly well-balanced even though direct reference to source culture was limited. The study concluded that the textbook included international cultures and can promote ICC in language classrooms. Çetin Köroğlu, (2016) investigated language instructors' opinions regarding 'English for Life' and found that it did not offer sufficient content about learners' native culture and challenge students' stereotypes. Toprak and Aksoyalp (2015) also analysed four different international language coursebook series. They aimed to identify the representation of innercircle countries in these textbooks rather than scrutinizing source culture or international cultures. They concluded that whereas the UK and the USA were presented frequently, the other English-speaking 
countries such as New Zealand and Canada were underrepresented. Erdoğan (2015) also evaluated the tasks and activities in 'The Big Picture B1/B1+' and concluded that intercultural components were limited in number and the attitudes dimension of IC was not adequately presented. Bulut and Arikan (2015) also conducted a content analysis on the reading passages of various textbooks used in the Turkish context, which encapsulated both locally published (i.e. New Bridge to Success \& Spotlight on English) and internationally published textbooks (e.g. Cutting Edge, Enterprise 4, and The New Headway). The results demonstrated that there was a lack of sensitivity to differences in nationality, gender, and disability. Tozun (2012) investigated 'Solutions' and found that there were idioms and paralinguistic input; nonetheless, foreign accents, slangs, and registers were absent in the textbook.

To summarize, a review of the literature uncovered that internationally published textbooks had generally limited cultural content regarding source culture (Alsaif, 2016; Alsofi, 2018; Böcü, 2016; Dimici et al., 2018; Kayapınar, 2009; Tas, 2010) and target culture was still the most dominant one compared to the home and international cultures (Alsaid, 2016; Shin et al., 2011; Dimici et al, 2018; Kayapınar, 2009; Tas, 2010). Moreover, some internationally published textbooks lacked content regarding stereotypes of home and target cultures and they did not encourage learners to challenge their views, and taboos (Çetin Köroğlu, 2016; Göktaş, 2013).

\subsection{Research questions}

In the Turkish context, whereas middle and high school students in state schools generally exploit a locally-published textbook which is prepared based on the national curriculum by the language teachers and materials developers, internationally published textbooks are generally preferred in foreign language learning programs at universities irrespective of the type of institution (i.e. private or state). This present study aimed to evaluate an internationally published ELT textbook that is utilized in language classes at a state university from an intercultural perspective. As opposed to the previous textbook evaluation studies which generally preferred the content analysis to reveal the intercultural components in the textbook; this present study was based on the learners' and teachers' perspectives upon the use of the textbook for a two-month period, so it was a retrospective evaluation rather than a predictive one based on Ellis's (1997) classification of materials evaluation. The research question was, therefore, formulated as given below:

1. What are the students 'and instructors' perceptions of the English textbook New Language Leader-Pre-intermediate with regard to intercultural competence?

\section{Method}

\subsection{Research context}

The research context was English preparatory school at a state university. The program aims to prepare learners so they could survive in their study at their faculties in the following years of their education. Students are required to have 75 out of 100 in the in-house assessment exam or they should present an equivalent score from an internationally recognized language test. Students have 25 hours of teaching per week. They have a chance to practice their language skills with extra-curricular activities such as some conversation sessions with international students and instructors.

\subsection{Material to be evaluated}

New Language Leader Pre-intermediate (Rees \& Lebeau, 2014) was specifically chosen for the study as a majority of the students were at the pre-intermediate level and they were using this textbook during the conduct of the study. The textbook consists of twelve units, which have been thematically 
organized. Each unit is comprised of five sections. At the end of the book, the language reference section gives detailed explanations regarding grammar structures and has some mechanical activities to practice the language structures presented through the written and spoken texts in the input session. The textbook also has 'Meet the Expert' section where students watch videos in which experts share some information about unit theme.

\subsection{Participants}

In this study, 132 foreign language learners studying at preparatory school at a state university and 15 instructors who were teaching English to these students responded to the questionnaire. Students' ages generally ranged between 18 and 21, but ten students were above 22. These students were studying at their second university or in the preparatory stage for their MA or $\mathrm{PhD}$. The number of male students was 51 whereas 81 female students responded to the questionnaire.

Table 1. Demographics of the teacher participants

\begin{tabular}{llc}
\hline & & $f$ \\
\hline Nationality & Turkish & 12 \\
& Other & 3 \\
Gender & Male & 3 \\
& Female & 12 \\
Teaching Experience & & \\
& 6-10 years & 5 \\
& 11-15 years & 7 \\
& 16-20 years & 3 \\
Degree & & \\
& BA & 4 \\
& MA/MSc & 9 \\
& PhD & 2 \\
\hline
\end{tabular}

As illustrated in Table 1, the number of instructors was 15 and all these instructors had used the textbook that was evaluated in this study. Twelve female and three male instructors responded to the survey. Their teaching experience ranged between 6 and 20 years. More than half of the participants had their master's degree.

\subsection{Instrument(s)}

A questionnaire developed by Skopinskaja (2003) was used in the study. Teachers responded to the English version whereas the scale was adapted to Turkish for the language learners as learners' English proficiency level was not sufficient to fully understand the questions in the questionnaire. For the Turkish version, expert opinion was asked and the questionnaire was implemented to two students for comprehensibility and face validity, and necessary revisions were done. Cronbach's alpha reliability coefficient value was .92 .

\subsection{Data collection and data analysis}

The Ethics Committee Approval was received from the university that the study was conducted and learners were informed about the questionnaire and the fact that they could leave the study at any time if they did not want to contribute. They signed the consent form and the questionnaire was implemented. Descriptive Statistics in SPSS was exploited to reveal the mean scores and frequencies for each item. Later they were presented via frequency tables. To compare teachers' and students' responses, the 
Mann-Whitney U test, which is a non-parametric test, was used as the data was not normally distributed based on participant type, instructor vs. student.

\section{Results}

When the findings of the survey were analysed, it was detected that the textbook was satisfactory in terms of serving the goals and interests of learners and including overall cultural content; however, some areas needed to be developed such as presentation of knowledge, attitudes, and awareness.

Regarding the aims and goals of the textbook, it was found that both $53.3 \%$ of the instructors and $47 \%$ of the students acknowledged that the goals of the textbook were appropriate to learners' conceptual framework to a large extent. $33.3 \%$ of the instructors also believed that the goals of the textbook corresponded to the students' needs and goals to a large extent whereas $60 \%$ believed this correspondence was to some extent. Students' responses reflected similar findings. $41.7 \%$ of the students believed that the goals of the textbook accorded with their needs to a large extent whereas 43.2\% thought this accordance was to some extent as can be examined in Table 2.

On the other hand, regarding the variety and pertinence of the topics, Mann-Whitney U test results demonstrated that there was a significant difference between students' and instructors' views on the suitability of the topics to students' interests determined by gender ( $p=.003)$, environment ( $p=.008)$, and social environment $(\mathrm{p}=.030)$. Students felt that the subjects appealed to their interests more than teachers thought.

Moreover, there was also a significant difference between students' and instructors' views on the indication of the goal of cultural instruction $(\mathrm{p}=.026)$. Students believed cultural instruction was referred to in the textbook to a large extent, but teachers indicated that it was only to some extent.

Table 2. Aims, goals and interests of the textbook

\begin{tabular}{|c|c|c|c|c|c|c|c|c|c|c|c|c|}
\hline & \multicolumn{5}{|c|}{$\underline{\text { Students }(\%)}$} & \multirow[t]{2}{*}{$\mathrm{M}$} & \multicolumn{5}{|c|}{$\underline{\text { Teachers }(\%)}$} & \multirow[t]{2}{*}{$\mathrm{M}$} \\
\hline & $\mathbf{0}$ & 1 & 2 & 3 & 4 & & $\mathbf{0}$ & 1 & 2 & 3 & 4 & \\
\hline $\begin{array}{l}\text { 1. The aims and goals of the textbook } \\
\text { are geared to the conceptual framework } \\
\text { of the students (as determined by their } \\
\text { age, social class, cultural background) }\end{array}$ & 0.8 & 8.3 & 37.3 & 47 & 6.8 & 2.51 & - & 6.7 & 40 & $\begin{array}{c}53 . \\
3\end{array}$ & - & 2.47 \\
\hline $\begin{array}{l}\text { 2. The aims and goals of the textbook } \\
\text { correspond to the needs and goals of } \\
\text { the students }\end{array}$ & 2.3 & 6.1 & 43.2 & 41.7 & 6.8 & 2.45 & - & 6.7 & 60 & $\begin{array}{c}33 . \\
3\end{array}$ & - & 2.27 \\
\hline \multicolumn{13}{|l|}{$\begin{array}{l}\text { 3. The textbook covers a variety of } \\
\text { topics suitable to the interests of the } \\
\text { students, as determined }\end{array}$} \\
\hline by their age & - & 5.3 & 26.5 & 45.5 & 22.7 & 2.86 & $\begin{array}{l}6 . \\
7\end{array}$ & 20 & $\begin{array}{l}13 . \\
3\end{array}$ & 60 & - & 2.27 \\
\hline sex (male /female) & 0.8 & 1.5 & 18.9 & 43.2 & 35.6 & 3.11 & - & 6.7 & $\begin{array}{c}46 . \\
7\end{array}$ & 40 & 6.7 & $2.47^{*}$ \\
\hline environment (urban/rural) & 2.3 & 6.1 & 23.5 & 43.9 & 24.2 & 2.82 & $\begin{array}{l}6 . \\
7\end{array}$ & $\begin{array}{c}13 . \\
3\end{array}$ & 40 & 40 & - & $2.13^{*}$ \\
\hline $\begin{array}{l}\text { social setting (middle } \\
\text { class/working class/farmers) }\end{array}$ & 3 & 3.8 & 28.8 & 40.2 & 24.2 & 2.79 & $\begin{array}{l}6 . \\
7\end{array}$ & $\begin{array}{c}13 . \\
3\end{array}$ & $\begin{array}{c}33 . \\
3\end{array}$ & $\begin{array}{c}46 . \\
7\end{array}$ & - & 2.20 \\
\hline $\begin{array}{l}\text { 4. The goal of the cultural instruction is } \\
\text { stated. }\end{array}$ & 0.8 & 14.4 & 31.1 & 47.7 & 6.1 & 2.44 & - & $\begin{array}{c}33 . \\
3\end{array}$ & 40 & $\begin{array}{c}26 . \\
7\end{array}$ & - & $1.93^{*}$ \\
\hline
\end{tabular}


Concerning the cultural content presented in the textbook, both students (\%40.2) and the instructors (\%53.3) thought that the textbook reflected the cultural character of the foreign society to a large extent or some extent as can be examined in Table 3. Almost half of the students and slightly over half of the instructors thought that cultural content was integrated into the textbook to a large extent.

Moreover, both students and instructors acknowledged that characters in the textbook represented foreign society regarding their social class, family situation, interests, mentality, and age to a large extent. There was also a significant difference between students' and instructors' views on the extent of representativeness of foreign society regarding social class $(\mathrm{p}=.041)$, students claimed that this representation was to a large extent and there were also students who believed that they were completely representative.

Table 3. Cultural content

\begin{tabular}{|c|c|c|c|c|c|c|c|c|c|c|c|c|}
\hline & \multicolumn{5}{|c|}{$\underline{\text { Students }(\%)}$} & \multirow[t]{2}{*}{$\mathrm{M}$} & \multicolumn{5}{|c|}{ Teachers (\%) } & \multirow[t]{2}{*}{$\mathrm{M}$} \\
\hline & $\mathbf{0}$ & 1 & 2 & 3 & 4 & & $\mathbf{0}$ & 1 & 2 & 3 & 4 & \\
\hline $\begin{array}{l}\text { 1. The textbook reflects the cultural } \\
\text { character of the foreign society }\end{array}$ & 1.5 & 24.2 & 24.2 & 40.2 & 9.8 & 2.33 & - & 13.3 & 53.3 & 33.3 & - & 2.20 \\
\hline $\begin{array}{l}\text { 2. The cultural content is integrated in } \\
\text { the course }\end{array}$ & 0.8 & 14.4 & 26.5 & 48.5 & 9.8 & 2.52 & 6.7 & - & 40 & 53.3 & - & 2.40 \\
\hline \multicolumn{13}{|l|}{$\begin{array}{l}\text { 3. The characters in the textbook are } \\
\text { representative of the foreign society with } \\
\text { regard to, }\end{array}$} \\
\hline Age & - & 9.8 & 30.3 & 50.8 & 9.1 & 2.59 & - & 13.3 & 46.7 & 40 & - & 2.27 \\
\hline their social class & 0.8 & 9.8 & 18.9 & 54.5 & 15.9 & 2.75 & - & 13.3 & 40 & 46.7 & - & $2.33^{*}$ \\
\hline their interests & 0.8 & 6.8 & 22 & 53 & 17.4 & 2.95 & - & - & 60 & 33.3 & $\begin{array}{l}6 \\
7\end{array}$ & 2.47 \\
\hline their mentality & 1.5 & 11.4 & 25 & 46.2 & 15.9 & 2.64 & - & 13.3 & 33.3 & 53.3 & - & 2.40 \\
\hline their family situation & 5.3 & 12.9 & 25 & 43.9 & 12.9 & 2.46 & - & 20 & 33.3 & 46.7 & - & 2.27 \\
\hline
\end{tabular}

Note. $0=$ Not at all $1=$ Not really $2=$ To some extent $3=$ To a large extent $4=$ Completely

With regard to the presentation of the knowledge component, as shown in Table 4, both instructors and the students thought that historical perspective, geographical perspective, and creative arts of the target language cultures (TLCs) were represented in the textbook to some extent although a quarter of the teachers did not think so. Though $39.4 \%$ of the students and $33.9 \%$ of the instructors believed that the political points of view of the TLCs were also taken into consideration to some extent, $25 \%$ of the students and $53.3 \%$ of the teachers believed that these were not exactly presented.

About the presentation of a range of subcultures i.e. professions, both teachers and students compromised that they existed in the textbook largely. Almost half of the instructors believed that a diverse range of cultures (British, American, Indian, African etc.) existed in the textbook to a large extent, and slightly over one-third of them believed they existed to some extent.

Although more than half of the students and almost half of the instructors believed that textbook provided insight into the socially acceptable or taboo topics of the TLCs to some extent or a large extent, $22 \%$ of the students and $40 \%$ of the instructors thought textbook did not exactly offer these topics. Moreover, even though $34.1 \%$ of the students and $46.7 \%$ of the teachers thought that the textbook provided insight into the racial, cultural, or gender stereotypes to some extent, $27.3 \%$ of the students and $33.3 \%$ of the instructors thought that the textbook did not offer this insight indeed. 
Another important finding is that majority of the students and more than half of the instructors compromised that insight into the students' own culture was not really offered or it was not even provided at all in the textbook as demonstrated in Table 4. Finally, 33.3\% of the students and slightly over half of instructors thought that insight into such socio-political issues as unemployment and pollution was provided in the textbook to some extent.

Table 4. Presentation of content: knowledge

\begin{tabular}{|c|c|c|c|c|c|c|c|c|c|c|c|c|}
\hline & \multicolumn{5}{|c|}{ Students (\%) } & \multirow[t]{2}{*}{$\mathrm{M}$} & \multicolumn{5}{|c|}{ Teachers $(\%)$} & \multirow[t]{2}{*}{$\mathrm{M}$} \\
\hline & 0 & 1 & 2 & 3 & 4 & & 0 & 1 & 2 & 3 & 4 & \\
\hline $\begin{array}{l}\text { 1. The historical perspective is present } \\
\text { to explain the national identity of the } \\
\text { TLCs }\end{array}$ & 6.1 & $\begin{array}{c}15 . \\
9\end{array}$ & $\begin{array}{c}38 . \\
6\end{array}$ & $\begin{array}{c}32 . \\
6 .\end{array}$ & 6.8 & 2.18 & - & $\begin{array}{c}26 . \\
7\end{array}$ & 60 & $\begin{array}{c}13 . \\
3\end{array}$ & - & 1.87 \\
\hline $\begin{array}{l}\text { 2. The geographical perspective is } \\
\text { present to explain certain features of } \\
\text { the national character of the TLCs }\end{array}$ & 3 & $\begin{array}{c}17 . \\
4\end{array}$ & $\begin{array}{c}36 . \\
4\end{array}$ & $\begin{array}{c}37 . \\
1\end{array}$ & 6.1 & 2.26 & - & $\begin{array}{c}26 . \\
7\end{array}$ & $\begin{array}{c}53 . \\
\mathbf{3}\end{array}$ & $\begin{array}{c}13 \\
3\end{array}$ & $\begin{array}{l}6 \\
\dot{7}\end{array}$ & 2.00 \\
\hline $\begin{array}{l}\text { 3. The political (also ideological and } \\
\text { religious) perspectives of TLCs are } \\
\text { taken into consideration }\end{array}$ & 9.1 & 25 & $\begin{array}{c}39 . \\
4\end{array}$ & $\begin{array}{c}17 . \\
4\end{array}$ & 9.1 & 1.92 & 6.7 & $\begin{array}{c}53 . \\
\mathbf{3}\end{array}$ & $\begin{array}{c}33 . \\
3\end{array}$ & - & 7 & 1.47 \\
\hline $\begin{array}{l}\text { 4. The textbook offers insight into the } \\
\text { creative arts of the TLCs }\end{array}$ & 5.3 & $\begin{array}{c}15 . \\
9\end{array}$ & $\begin{array}{c}33 . \\
3\end{array}$ & $\begin{array}{c}37 . \\
1\end{array}$ & 8.3 & 2.27 & - & $\begin{array}{c}33 . \\
3\end{array}$ & $\begin{array}{c}46 . \\
7\end{array}$ & $\begin{array}{c}13 . \\
3\end{array}$ & $\begin{array}{l}6 \\
7\end{array}$ & 1.93 \\
\hline $\begin{array}{l}\text { 5. The textbook offers insight into a } \\
\text { variety of cultures (for example, } \\
\text { British, American, Indian, African, } \\
\text { etc.) }\end{array}$ & 4.5 & $\begin{array}{c}19 . \\
7\end{array}$ & $\begin{array}{c}27 . \\
3\end{array}$ & $\begin{array}{c}37 . \\
9\end{array}$ & $\begin{array}{c}10 . \\
6\end{array}$ & 2.30 & 6.7 & 6.7 & $\begin{array}{c}33 . \\
3\end{array}$ & $\begin{array}{c}46 . \\
7\end{array}$ & $\begin{array}{l}6 \\
7\end{array}$ & 2.40 \\
\hline $\begin{array}{l}\text { 6. The textbook offers insight into a } \\
\text { variety of subcultural groups (namely, } \\
\text { professions) }\end{array}$ & 0.8 & $\begin{array}{c}12 . \\
9\end{array}$ & 28 & $\begin{array}{c}44 . \\
7\end{array}$ & $\begin{array}{c}13 . \\
6\end{array}$ & 2.58 & 7.1 & 7.1 & $\begin{array}{c}42 . \\
9\end{array}$ & 42. & - & 2.21 \\
\hline $\begin{array}{l}\text { 7. The textbook offers insight into the } \\
\text { socially acceptable or taboo topics of } \\
\text { the TLCs }\end{array}$ & 8.3 & 22 & $\begin{array}{c}34 . \\
8\end{array}$ & $\begin{array}{c}29 . \\
5\end{array}$ & 5.3 & 2.02 & $\begin{array}{c}13 . \\
3\end{array}$ & 40 & 20 & $\begin{array}{c}26 . \\
7\end{array}$ & - & 1.60 \\
\hline $\begin{array}{l}\text { 8. The textbook offers insight into the } \\
\text { cultural/racial/gender stereotypes }\end{array}$ & 9.8 & $\begin{array}{c}27 . \\
3\end{array}$ & $\begin{array}{c}34 . \\
1\end{array}$ & $\begin{array}{c}25 \\
8\end{array}$ & 3 & 1.85 & 6.7 & $\begin{array}{c}33 . \\
3\end{array}$ & $\begin{array}{c}46 . \\
7\end{array}$ & $\begin{array}{c}13 . \\
3\end{array}$ & - & 1.67 \\
\hline $\begin{array}{l}\text { 9. The textbook offers insight into the } \\
\text { students' own culture }\end{array}$ & $\begin{array}{c}33 . \\
3\end{array}$ & $\begin{array}{c}37 . \\
1\end{array}$ & $\begin{array}{c}14 . \\
4\end{array}$ & $\begin{array}{c}13 . \\
6\end{array}$ & 1.5 & 1.13 & $\begin{array}{c}26 . \\
7\end{array}$ & $\begin{array}{c}33 . \\
3\end{array}$ & $\begin{array}{c}26 . \\
7\end{array}$ & $\begin{array}{c}13 . \\
3\end{array}$ & - & 1.27 \\
\hline $\begin{array}{l}\text { 10. The textbook offers insight into } \\
\text { socio-political problems of the TLCs } \\
\text { (unemployment, pollution, etc.) }\end{array}$ & 7.6 & 22 & $\begin{array}{c}33 . \\
3\end{array}$ & $\begin{array}{c}28 \\
8\end{array}$ & 8.3 & 2.08 & $\begin{array}{c}13 \\
3\end{array}$ & $\begin{array}{c}13 . \\
3\end{array}$ & $\begin{array}{c}53 . \\
3\end{array}$ & $\begin{array}{c}13 . \\
3\end{array}$ & $\begin{array}{l}6 \\
\dot{7}\end{array}$ & 1.87 \\
\hline
\end{tabular}

Note. $0=$ Not at all $1=$ Not really $2=$ To some extent $3=$ To a large extent $4=$ Completely

Regarding the presentation of the attitude component of intercultural competence, $40.2 \%$ of the students and $46.7 \%$ of the instructors thought that the textbook developed tolerance to some extent. 40.2 $\%$ of the students thought that the textbook offered empathy towards otherness to a large extent and similarly $40 \%$ of the instructors thought it was provided to some extent.

The majority of instructors and students thought the textbook challenged students' existing stereotypes to some or a large extent. However, there were also $37.2 \%$ of the learners and $20 \%$ of the instructors who believed the textbook did not truly challenge learners' current stereotypes or it did not challenge at all.

Even though more than half of the teachers believed the textbook contributed to the development of a sense of national identity as well as the consciousness of being an international community either to 
some extent or to a large extent, $22.7 \%$ of the students and $33.3 \%$ of the instructors thought it did not entirely develop such feelings.

Both students (36.4\%) and instructors (53.4\%) believed that the textbook prepared students to behave adequately in intercultural interactions to a large extent. They also thought that it aroused interest in learners about other cultures.

Table 5. Presentation of content: attitudes

\begin{tabular}{|c|c|c|c|c|c|c|c|c|c|c|c|c|}
\hline & \multicolumn{5}{|c|}{$\underline{\text { Students }(\%)}$} & \multirow[t]{2}{*}{$\mathrm{M}$} & \multicolumn{5}{|c|}{ Teachers $(\%)$} & \multirow[t]{2}{*}{$\mathrm{M}$} \\
\hline & $\mathbf{0}$ & 1 & 2 & 3 & 4 & & $\mathbf{0}$ & 1 & 2 & 3 & 4 & \\
\hline $\begin{array}{l}\text { 1. The textbook develops tolerance } \\
\text { towards otherness }\end{array}$ & 5.3 & 11.4 & 40.2 & 34.8 & 8.3 & 2.30 & - & 20 & 46.7 & 26.7 & $\begin{array}{l}6 . \\
7\end{array}$ & 2.20 \\
\hline $\begin{array}{l}\text { 2. The textbook develops empathy } \\
\text { towards otherness }\end{array}$ & 4.5 & 15.9 & 32.6 & 40.2 & 6.8 & 2.29 & - & 20 & 40 & 33.3 & $\begin{array}{l}6 . \\
7\end{array}$ & 2.27 \\
\hline $\begin{array}{l}\text { 3. The textbook challenges the } \\
\text { students' existing stereotypes }\end{array}$ & 15.2 & 22 & 27.3 & 34.1 & 1.5 & 1.85 & - & 20 & 46.7 & 26.7 & $\begin{array}{l}6 . \\
7\end{array}$ & 2.20 \\
\hline $\begin{array}{l}\text { 4. The textbook develops a feeling of } \\
\text { the national identity (and an awareness } \\
\text { of being a member of an international } \\
\text { community as well) }\end{array}$ & 9.1 & 22.7 & 30.3 & 31.8 & 6.1 & 2.03 & $\begin{array}{l}6 . \\
7\end{array}$ & $\begin{array}{c}33 . \\
3\end{array}$ & 33.3 & 26.7 & - & 1.80 \\
\hline $\begin{array}{l}\text { 5. The textbook encourages curiosity } \\
\text { about the other culture(s) }\end{array}$ & 7.6 & 15.2 & 30.3 & 31.8 & 15.2 & 2.32 & - & $\begin{array}{c}13 . \\
3\end{array}$ & 53.3 & 33.3 & - & 2.20 \\
\hline $\begin{array}{l}\text { 6. The textbook prepares students to } \\
\text { behave adequately when in contact } \\
\text { with the members of other culture(s) }\end{array}$ & 5.3 & 20.5 & 26.5 & 36.4 & 11.4 & 2.28 & - & 6.7 & 40 & 53.4 & - & 2.47 \\
\hline
\end{tabular}

Note. $0=$ Not at all $1=$ Not really $2=$ To some extent $3=$ To a large extent $4=$ Completely

About the intercultural awareness, Table 6 illustrates that both instructors and students noted that the textbook encouraged learners to have comparisons between their own culture and the foreign culture to some extent or large extent. Although the majority of teachers and more than half of the learners thought that both foreign cultures' and their own cultures' mutual images, and stereotypes existed in the textbook, $24.2 \%$ of the students and $26.7 \%$ of the instructors thought it was not precisely the case. There were even $10.6 \%$ of the students who believed they were not presented at all.

Table 6. Presentation of content: intercultural awareness

\begin{tabular}{|c|c|c|c|c|c|c|c|c|c|c|c|c|}
\hline & \multicolumn{5}{|c|}{ Students (\%) } & \multirow[t]{2}{*}{$\mathrm{M}$} & \multicolumn{5}{|c|}{ Teachers (\%) } & \multirow[t]{2}{*}{$\mathrm{M}$} \\
\hline & $\mathbf{0}$ & 1 & 2 & 3 & 4 & & 0 & 1 & 2 & 3 & 4 & \\
\hline $\begin{array}{l}\text { 1. The textbook encourages students to } \\
\text { compare the foreign culture with their } \\
\text { own (namely, to observe and analyse } \\
\text { similarities and differences between } \\
\text { their own and the foreign culture) }\end{array}$ & 5.3 & 17.4 & 34.1 & 30.3 & 12.9 & 2.28 & - & 13.3 & 20 & 60 & 6.7 & 2.60 \\
\hline $\begin{array}{l}\text { 2. The textbook offers mutual } \\
\text { representations, images and stereotypes } \\
\text { of the students' own and the foreign } \\
\text { culture }\end{array}$ & 10.6 & 24.2 & 37.9 & 20.5 & 6.8 & 1.89 & - & 26.7 & 66.7 & 6.7 & - & 1.80 \\
\hline
\end{tabular}


Regarding the relationship between language and culture, the majority of participants thought that the textbook enhanced awareness of different linguistic and paralinguistic means to indicate students' attitudes to some extent. However, $21.2 \%$ of the learners and $20 \%$ of the instructors believed it did not entirely enhance paralinguistic means such as gesture, body language, and intonation, as illustrated in Table 7.

Table 7. Presentation of content: culture and language

\begin{tabular}{|c|c|c|c|c|c|c|c|c|c|c|c|c|}
\hline & \multicolumn{5}{|c|}{ Students (\%) } & \multirow[t]{2}{*}{$\mathrm{M}$} & \multicolumn{5}{|c|}{ Teachers $(\%)$} & \multirow[t]{2}{*}{$\mathrm{M}$} \\
\hline & 0 & 1 & 2 & 3 & 4 & & 0 & 1 & 2 & 3 & 4 & \\
\hline $\begin{array}{l}\text { 1. The cultural context of the textbook } \\
\text { develops students' awareness of } \\
\text { different linguistic means to express } \\
\text { their attitudes }\end{array}$ & $\begin{array}{c}3.8 \\
4\end{array}$ & 16.7 & 34.8 & 40.2 & 4.5 & 2.25 & $\begin{array}{l}6 \\
7\end{array}$ & - & 60 & $\begin{array}{c}33 . \\
3\end{array}$ & - & 2.20 \\
\hline $\begin{array}{l}\text { 2. The textbook develops students' } \\
\text { awareness of the paralinguistic (e.g } \\
\text { body language, gesture, intonation } \\
\text { etc.) means to express their attitudes }\end{array}$ & 7.6 & 21.2 & 39.5 & 35.6 & 6.1 & 2.11 & - & $\begin{array}{l}2 \\
0\end{array}$ & $\begin{array}{c}33 . \\
3\end{array}$ & 40 & 6.7 & 2.33 \\
\hline $\begin{array}{l}\text { 3. The textbook teaches the register } \\
\text { appropriate to the students' needs } \\
\text { (formal-informal, slang, regional } \\
\text { idioms, etc.) }\end{array}$ & $\begin{array}{c}15 \\
2\end{array}$ & $\begin{array}{c}20.5 \\
1\end{array}$ & 30.2 & 39.5 & 4.5 & 1.89 & $\begin{array}{l}6 \\
\dot{7}\end{array}$ & - & $\begin{array}{c}53 . \\
\mathbf{3}\end{array}$ & $\begin{array}{c}33 . \\
3\end{array}$ & 6.7 & 2.33 \\
\hline $\begin{array}{l}\text { 4. The material used in the texts, } \\
\text { exercises, tapes, etc. is authentic }\end{array}$ & 0.8 & 11.4 & 25.8 & 41.7 & $\begin{array}{c}20 . \\
5\end{array}$ & 2.70 & - & $\begin{array}{l}1 \\
3 . \\
3\end{array}$ & $\begin{array}{c}33 . \\
3\end{array}$ & 40 & $\begin{array}{c}13 . \\
3\end{array}$ & 2.53 \\
\hline
\end{tabular}

Note. $0=$ Not at all $1=$ Not really $2=$ To some extent $3=$ To a large extent $4=$ Completely

Participants also thought that the textbook taught the register suitable for the students' needs to some extent or a large extent, yet there were $20.51 \%$ of learners who believed it did not do so. Besides, $15 \%$ of them even reported that it did not teach the register at all. Finally, both students and teachers also believed that the texts, exercises, and tapes in the book were authentic to a large extent.

\section{Discussion}

The results of this study showed that New Language Leader Pre-intermediate was satisfactory in terms of inclusion of a variety of cultures, which was similar to the findings of the previous research on internationally published textbooks (Alsofi, 2018; Böcü \& Razı, 2016; Kayapınar, 2009; Taş, 2010). Since English is taught in many contexts as an international language, the place of culture in the textbooks was questioned by many scholars earlier (Alptekin, 2002; Baker, 2012). Textbooks that present only the TLCs do not meet the needs and expectations of the language learners who learn EIL (Alptekin, 2002; Cortazzi \& Jin, 1999; Shin et al., 2011; Alsaif, 2016). Tomlinson (2005) advocates that language teaching materials utilized in countries where English is used as a foreign language should have priority to help learners to communicate not only with native speakers of English but also with non-native speakers of English because the interaction between non-native speakers of English comprises over the half of the total interaction in English. Therefore, textbook authors should also consider the impact of the development of EIL in foreign language instruction. And textbooks should include perspectives, practices, and products of a diverse set of cultures to meet the communication needs of the members of local and global contexts (Baker, 2012; Çelik \& Erbay, 2013). 
The textbook under investigation was also appreciated by the learners and instructors as it corresponded to the students' conceptual framework, needs, goals, and interests to a large extent. The textbook was also highly regarded in terms of integrating overall cultural content and representation of foreign societies by the textbook characters. Participants, especially learners, believed authentic texts, tapes, and exercises existed in the textbook to a large extent.

On the other hand, some areas needed to be developed in the textbook including insight into students' own culture, political perspectives and socio-political problems of the TLCs, socially appropriate and inappropriate topics of the TLCs, insight into gender, racial and cultural stereotypes of both students' own culture and the TLCs, challenging students' existing stereotypes, developing a feeling of national and international identity and use of formal and informal language use, slang and regional idioms.

A lack of insight into students' own culture was also detected in the earlier studies (Alsaif, 2016; Alsofi, 2018; Amarian \& Tajabadi, 2020; Böcü \& Raz1, 2016; Çetin Köroğlu, 2016; Dimici et al., 2018; Taş, 2010) that investigated internationally published textbooks. This finding implies that the textbook under investigation and other similar internationally published textbooks could be revised based on the cultural context of the language teaching environment. As Aliakbari (2004) claimed, one advantage of having source culture in the textbook is that students see the members of their own country speak English, so the topics, characters, and the contexts are familiar for the learners. Furthermore, the representation of source culture in the textbooks provides learners with an equal opportunity to raise issues in their own culture and elaborate on their cultural framework (Alsaif, 2016). Most importantly, as McKay (2002) acknowledged, knowing one's own culture promotes the understanding of cultures of others; therefore, students might be provided opportunities where they start with their own cultural framework, especially by critically analysing it and then they compare it with new frameworks provided with the TLCs and many other international cultures as well. So, one task of language teachers should be to take the students from what they know to what they are not acquainted with by emphasizing the need for respect for all societies and cultures in the world (Alsaif, 2016).

On the other hand, the inclusion of a wide range of cultures should not lead to stereotyping of the different cultures. It has long been acknowledged in the literature that stereotypical content about various cultures is prevalent in English language course materials (Garcia, 2005). The results of this particular study also showed that insight into gender, racial and cultural stereotypes of both students' own culture and the TCs was limited, and some students even believed the textbook did not challenge their stereotypes at all. Çetin Köroğlu (2016) also found that an internationally published book 'English for Life' did not fully challenge students' stereotypes. Göktaş (2013) also found similar results in his evaluation of 'English Unlimited', and learners thought that the textbook did not motivate them to critically evaluate cultural stereotypes. Therefore, the activities in international textbooks should develop a sense of critical judgement of the stereotyping values and practices of other cultures. As Ndura (2004) suggested learners need to be aware that they can challenge and question the viewpoints presented in the textbooks. Gray (2000) also remarks that by encouraging students to see materials as more than just linguistic objects, teachers might allow students to express their views and change the one-way information flow besides developing their language skills. As a result, intercultural elements in the textbooks are not restricted to the specific and stereotypical knowledge about the target and other cultures. Issues regarding stereotyping, culture shock, and misunderstanding in cross-cultural situations should be referred to by the material writers (Damen, 2003). Even textbooks could be supported with some extra materials and tasks. For instance, as Gedik Bal (2020) also recommended, speaking and writing tasks might be assigned to the learners based on the themes that hamper stereotyping and ethnocentrism.

Regarding the lack of political, religious, and ideological perspectives in the textbook, Dimici et al. (2018) also found that political orientations were rarely observed in the textbook. Amerian and Tajabadi 
(2020) had similar findings upon the teachers' evaluation of the 'New Headway' internationally published textbook. The textbooks might intentionally avoid such issues in the fear that such topics might lead to conflicts among the students. However, textbook authors should embrace a critical perspective concerning the realities of the world, and certain issues such as ideologies of different societies and human rights should be incorporated. Critical reflection should also be supported in language classrooms and teachers need to be well-equipped to manage any conflicts in the classroom.

Some students also believed that the use of formal-informal language and slang was limited. This finding was similar to Tozun's (2012) evaluation of an internationally published textbook 'Solution' as it had no reference to register or slang. As it is not authentic to present only the formal language in the textbooks, more colloquial language use should also be offered so that students are well prepared for the actual and informal use of language outside the classroom. Moreover, half of the teachers thought that the textbook did not provide much insight into acceptable and unacceptable norms in the target societies. It might be suggested that textbooks include some tasks and activities that learners are required to have some inferences to analyse and solve the communication problems in the cases where conflicts are available. In that way, students are encouraged to think critically and reflect on cultural frameworks and they do not need to be provided with to-do and not-to-do lists in a wide array of cultures, which might even lead to overgeneralization.

\section{Conclusions}

This textbook evaluation study was conducted to cast light on the potential of a textbook, which was written by international authors, in terms of promoting IC of language learners. The findings revealed that both instructors and students found the textbook successful in terms of presenting the cultural content, including authentic texts, tapes, and exercises, diverse topics that interest learners in addition to book characters' representativeness of the foreign society. However, it was limited as it did not promote much insight into learners' own culture, stereotypes of home and target cultures and did not involve admissible or impermissible topics of the target cultures.

As international textbooks target language learners from all around the world, they might have a more global approach to the integration of cultural content in the textbooks. Nonetheless, it should also be noted that acquiring IC also requires the knowledge of source culture in relation to the TLCs and international cultures as well. Therefore, international textbooks should integrate some activities where students have a chance to reflect on their own culture and the parallel and distinctive features of their own and foreign cultures. These tasks might be further developed with some critical incidents where individuals from various cultures have misunderstandings because of a lack of cultural knowledge, cultural beliefs, and values, yet these should not lead to stereotyping of some dominant cultures. On the contrary, textbooks ought to provide a wide array of tasks and activities where learners get informed and reflect on stereotyping, and the ways to overcome these. It should also be noted that textbooks are just a component of the intriguing dynamics of language classrooms and teachers and learners are the agents that can get the most benefit from the textbook content.

There are certain limitations, one of which is that evaluation was based on the use of a single textbook in a specific context. Therefore, further research might be conducted on the other levels of the textbook series in diverse contexts. Another limitation was the limited means of evaluation. Apart from the questionnaire, the study might have been triangulated with other data collection techniques such as interviews with students and instructors. Even participant triangulation might have been realized through interviews with publishers and the writers of the textbook, which was not possible in this particular 
study. Further research via participant observation might also be conducted on how the textbook is exploited in the language classroom to promote intercultural skills.

\section{Ethics Committee Approval}

The author affirms that the Ethics Committee Approval was received from the university that the study was conducted (Decision no: 2020/4630).

\section{Acknowledgements}

A previous version of this study was presented in the 11th International Research Conference organized by Çanakkale Onsekiz Mart University, Faculty of Education, ELT Department on 03-05 September 2020.

\section{References}

Abbasian, R, \& Biria, R. (2017). English language textbooks in EFL Education: Do improve students' national, international and target culture familiarity?. Khazar Journal of Humanities and Social Sciences, 20(2), 49-65.

Äijälä, H. (2009). Acquiring intercultural competence from course books: Analysis of learning tasks in the Finnish upper secondary school course book series In Touch, University of Tampere.

Aliakbari M. (2004). "The place of culture in the Iranian ELT textbooks in high school level", in: 9th Pan-Pacific Association of Applied Linguistics Conference, Namseoul University, Korea.

Alptekin, C. (2002). Towards intercultural communicative competence in ELT. ELT Journal, 56(1), 57 64.

Alsaif, O. (2016). A variety of cultures represented in English language textbooks: A critical study at Saudi university. Sociology Study, 6(4), 226-244.

Alsofi, B. B. M. (2018). An evaluation of the cultural aspects in the university English textbook, Well Read 1. Theory and Practice in Language Studies, 8(2), pp. 184-196.

Amerian, M., \& Pouromid, S. (2018). Language teachers' beliefs on materials use and their locus of control: Case Studies from Iran and Japan. Indonesian Journal of Applied Linguistics, 7(3), 583-593.

Amerian, M., \& Tajabadi, A. (2020). The role of culture in foreign language teaching textbooks: an evaluation of New Headway series from an intercultural perspective. Intercultural Education, 1-22.

Atay, D. (2005). Reflections on the cultural dimension of language teaching. Language and Intercultural Communication, 5(3-4), 222-236.

Baker, W. (2012). From cultural awareness to intercultural awareness: Culture in ELT. ELT Journal, 66(1), 62-70.

Bennet, J. M., \& Bennet, M. J. (2004). Developing intercultural sensitivity: An integrative approach to global and domestic diversity. In D. Landis, J.M Bennett, \& M.J. Bennett (Eds.), Handbook of Intercultural Training (pp.145-167). Thousand Oaks, CA: Sage.

Böcü, A. B., \& Razı, S. (2016). Evaluation of textbook series 'Life' in terms of cultural components. Journal of Language and Linguistic Studies, 12(2), 221-237. 
Bulut, M., \& Arıkan, A. (2015). Socially responsible teaching and English language coursebooks: Focus on ethnicity, sex, and disability. E-Journal of Yaşar University, 10, 13-20.

Byram, M. (1997). Teaching and Assessing Intercultural Competence. Clevedon, England: Multilingual Matters.

Council of Europe (2018). Common European Framework of Reference for Languages: Learning, Teaching, Assessment (Companion volume with new descriptors). Cambridge University Press, Cambridge, England.

Cortazzi M., \& Jin L. (1999). Cultural mirrors: Materials and methods in the EFL classroom, in: E. Hinkel (Ed.), Culture in Second Language Teaching (pp. 196-219).Cambridge, Cambridge University Press.

Çakır, I. (2010). The frequency of culture-spesific elements in the ELT course books in Turkey. Novitas- ROYAL (Research on Youth and Language), 4(2), 182-189.

Çelik, S., \& Erbay, S. (2013). Cultural perspectives of Turkish ELT course books: Do standardized teaching texts incorporate intercultural features? Education and Science, 38(167), 336-351.

Çetin Köroğlu, Z. (2016). An investigation on intercultural communicative competence's integration into textbooks; Language instructors' perspectives. Kastamonu Education Journal, 24(2), 619-632.

Damen, L. (2003). Closing the language and culture gap. In D.L. Lange \& R.M. Paige (Eds.), Culture as the Core: Perspectives on Culture in Second Language Learning (pp. 71-88). Greenwich, CT: Information Age Publishing.

Demirbas, M. N. (2013). Investigating intercultural elements in English coursebooks. Ahi Evran Üniversitesi Kirsehir Egitim Fakültesi Dergisi, 14(2), 291-304.

Dimici, K. Yıldız, B., \& Basbay, A. (2018). An analysis of an English coursebook (English File) in terms of multiculturalism. Journal of Language Education and Research, 4(3), 175-200.

Ellis, R. (1997). The empirical evaluation of language teaching materials. ELT Journal 51(1), 36-42.

Erdoğan, S. B. (2015). Acquiring intercultural competence from coursebooks: An analysis of learning tasks in the course book "The Big Picture" (Unpublished master's thesis). Çukurova University, Mersin.

Garcia, M. C. M. (2005). International and intercultural issues in English teaching textbooks: The case of Spain. Intercultural Education, 16(1). 57-68.

Gedik Bal, N. (2020). Intercultural sensitivity of EFL learners at a state university. The Journal of Language Teaching and Learning, 10(2), 1-19.

Ghanem, C. (2017). Teaching intercultural communicative competence: The perspective of foreign language graduate students instructors. International Journal for the Scholarship of Teaching and Learning, 11(2), 1-9.

Göktaş, Y. (2013). Place of multiculturalism in "English Unlimited" used at university Preparatory classes in Turkey (Unpublished master's thesis). Hacettepe University, Ankara.

Gray, J. (2000). The ELT coursebook as cultural artefact: How teachers censor and adapt. ELT Journal, 54(3), 274-282.

Hammer, M.R. (2015). Intercultural competence development. In J.M. Bennett (Ed.), The SAGE Encyclopedia of Intercultural Competence (pp. 483-486). The United States of America: Sage. 
Hatipoğlu, Ç. (2012). British culture in the eyes of future English language teachers in Turkey. In Y. Bayyurt \& Y. Bektas-Çetinkaya (Eds.), Research Perspectives on Teaching and Learning English in Turkey: Policies and Practices (pp. 119-144). Frankfurt: Peter Lang.

Kahraman, A. (2016). Teachers' and learners' attitudes towards culture and culture learning in a Turkish context. Journal of Language and Linguistic Studies, 12(2), 01-12.

Karahan Üzülmez, Y.\& Karakuş, F. (2018). Ortaokul İngilizce dersi öğretim programının ve İngilizce ders kitaplarının çokkültürlülük açısından incelenmesi. Turkish Studies, 13(11), 773-802.

Kayapınar, U. (2009). Coursebook evaluation by English teachers. İnönü Üniversitesi Eğitim Fakültesi Dergisi, 10(1), 68-78.

Kelly, M. (2012). Second language teacher education. In J. Jackson (Ed.), The Routlege Handbook of Language and Intercultural Communication (pp.409-421). New York, NY: Routledge.

Liddicoat, A. J., Papademetre, L., Scarino, A., \& Kohler, M. (2003). Report on intercultural language learning. Canberra ACT: Commonwealth of Australia.

Majdzadeh, M. (2002). Disconnection between language and culture: A case study of Iranian English textbooks. ERIC Document Reproduction Service No. ED 474691.

McKay, S. L. (2002). Teaching English as an international language: Rethinking goals and perspectives. New York: Oxford University Press.

Ndura, E. (2004). ESL and cultural bias: an analysis of elementary through high school textbooks in the Western United States of America, Language, Culture and Curriculum, 17(2), 143-153.

Rees, G., \& Lebeau, I. (2014). New Language Leader Pre-intermediate. Harlow, UK: Pearson Education Limited.

Ryan, P. (2012). The English as a foreign or international language classroom. In J. Jackson (Ed.), The Routlege Handbook of Language and Intercultural Communication (pp.422-431). New York, NY: Routledge.

Sercu, L. (2005). Teaching foreign languages in an intercultural world. In L. Sercu et al. (Ed.), Foreign language teachers and intercultural competence: An international investigation (pp.1-18). Clevedon, England: Multilingual Matters.

Shin, J., Eslami, Z. R., \& Chen, W. (2011). Presentation of local and international culture in current international English-language teaching textbooks. Language, Culture and Curriculum, 24(3), 253268.

Siddiqie, S. A. (2011). Intercultural exposure through English language teaching: An analysis of an English language textbook in Bangladesh. Journal of Pan-pacific Association of Applied Linguistics, 15(2), 109-127. Retrieved from: https://files.eric.ed.gov/fulltext/EJ979918.pdf

Skopinskaja, L. (2003). The role of culture in foreign language teaching materials: An evaluation from an intercultural perspective. In I. Lázár (Ed.), Incorporating intercultural communicative competence in language teacher education (pp. 39-58). Kapfenberg: Council of Europe Publishing.

Spitzberg B. H., \& Changnon G. (2009). Conceptualizing intercultural competence. In D. K. Deardorff (Ed.), The SAGE Handbook of Intercultural Competence (pp. 2-52) Thousand Oaks, CA, Sage.

Taş, S. (2010). A critical evaluation of New English File series in terms of culture teaching. Sosyal Bilimler Arastirmalari Dergisi, 1(2), 168-177. 
Tomlinson, B. (2005). The future for ELT materials in Asia, Electronic Journal of Foreign Language Teaching, 2(2), 5-13.

Tomlinson, B. (2012). Materials development for language learning and teaching, Language Teaching, 45(2), 143-179.

Toprak, T. E., \& Aksoyalp, Y. (2015). The question of re-presentation in EFL coursebooks: Are learners of English taught about New Zealand?. International Journal of Society, Culture \& Language, 3(1), 91-104.

Tozun, Z. (2012). Global English language and culture teaching in TRNC secondary EFL classroom: Teachers' perceptions and textbooks (Unpublished master's thesis). Eastern Mediterranean University, Gazimağusa, North Cyprus.

Zhang, Y. (2017). A study on ESL teachers' intercultural communication competence. English Language Teaching, 10(11), 229-235.

\section{Öğrencilerin ve öğretmenlerin yabancı dil kitabını kültürlerarası yönden değerlendirmesi}

\section{$\ddot{\mathbf{O z}}$}

Öğretmenler yabancı dil öğretiminde öncelikli olarak ders kitaplarına bel bağladıkları için, kültürlerarası beceri (KB) odaklanmalarına yardımcı olmanın ve onları teşvik etmenin bir yolu, onlara diğer dil becerilerinin yanı sıra KB öğrenmeyi kolaylaştıran ders kitapları sağlamaktır. Bu nedenle, bu çalışma New Language Leader Orta Öncesi Düzeyi ders kitabını kültürlerarası açıdan değerlendirmeyi amaçlamıştır. $\mathrm{Bu}$ değerlendirme, bir devlet üniversitesindeki hazırlık okulunda dil derslerinde iki ay boyunca kitabı kullandıktan sonra, 132 ögrencinin ve 15 öğretmenin ders kitabına ilişkin algılarına dayanmaktadır. Veri toplama aracı daha önceki bir çalışmadan uyarlanan bir ankettir. Veri analizi SPSS yardımıyla yapılmıştır. Frekansları ve ortalamaları hesaplamak için Betimleyici İstatistikler kullanılmıştır. Mann Whitney U Testi, öğrencilerin ve eğitmenlerin bakış açılarındaki olası önemli farkları keşfetmek için kullanılmıştır. Sonuçlar, katılımcılara göre bilgi, tutum, farkındalık ve dilbilimsel araç gibi KB bileşenlerinin çoğunun ders kitabında mevcut olmasına rağmen, bunların ders kitabındaki temsili derecesinin değişiklik gösterdiğini açığa çıkarmıştır. Ders kitabının amaç ve hedeflerinin, öğrencilerin kavramsal çerçevesine büyük ölçüde uygun olduğu düşünülürken, hem öğrenciler hem de eğitmenler, öğrencilerin kendi kültürleri hakkında çok fazla bilgi sağlamadığını belirtmiştir. Bulgular göz önüne alındığında, paydaşlar ders kitabı üzerinde gerekli değişiklikleri yapabilir ve eğitmenler, benzer bağlamlarda KB'nin geliştirilmesinde öğrencilerinin ihtiyaçlarını karşılamak için bazı kaynakları uyarlayabilirler.

Anahtar sözcükler: Kültür ve dil; kültürlerarası beceri; ders kitabı değerlendirmesi; yabancı dil öğrenimi; uluslararası dil olarak İngilizce

\section{AUTHOR BIODATA}

Nur Gedik Bal is an instructor at Social Sciences University of Ankara. She has received her BA, MA and PhD in English Language Teaching (ELT) at Middle East Technical University (METU). Her scholarly interests include intercultural competence of language learners and teachers, teachers' professional development, integrating technology into foreign language classrooms, and written corrective feedback. 